\title{
Rupture of a coronary artery aneurysm in Kawasaki disease: A rare case and review of the literature for the past 15 years
}

\author{
Takashi Miyamoto, MD, PhD, ${ }^{\mathrm{a}}$ Kentaro Ikeda, $\mathrm{MD},{ }^{\mathrm{b}}$ Youichirou Ishii, $\mathrm{MD}, \mathrm{PhD},{ }^{\mathrm{b}}$ and \\ Tomio Kobayashi, MD, PhD, ${ }^{\mathrm{b}}$ Gunma, Japan
}

We describe the rare case of a 3-month-old boy who had a ruptured coronary artery aneurysm (CAA) in the right coronary artery (RCA) combined with multiple CAAs in the left circumflex and left anterior descending coronary arteries. We also present a statistical analysis of all the ruptured CAAs previously reported and review the literature of the past 15 years, focusing on the location, etiology, diagnosis, management, and prognosis of giant CAAs.

\section{CLINICAL SUMMARY}

A 3-month-old Japanese boy was admitted to a neighborhood hospital with reported fever 2 days in duration and neck pain. He was treated for Kawasaki disease with intravenous immunoglobulin (IVIG; $2 \mathrm{~g} / \mathrm{kg}$ ) on days 5 and 8 of

\footnotetext{
From the Departments of Cardiovascular Surgery, ${ }^{\mathrm{a}}$ and Pediatric Cardiology, ${ }^{\mathrm{b}}$ Gunma Children's Medical Center, Gunma, Japan.

Disclosures: Authors have nothing to disclose with regard to commercial support.

Received for publication Dec 13, 2013; revisions received Feb 4, 2014; accepted for publication Feb 10, 2014

Address for reprints: Takashi Miyamoto, MD, PhD, 779 Shimohakoda, Hokkitsu,

Shibukawa, Gunma 377-8577, Japan (E-mail: yonomiyataka@msn.com).

J Thorac Cardiovasc Surg 2014;147:e67-9

0022-5223/ $\$ 36.00$

Copyright (c) 2014 by The American Association for Thoracic Surgery

http://dx.doi.org/10.1016/j.jtcvs.2014.02.035
}

illness and with prednisolone sodium metazoate (INN prednisolone; $2 \mathrm{mg} / \mathrm{kg} / \mathrm{d}$ ). He was transferred to our hospital for further management. At admission, the patient's abnormal laboratory findings included a white blood cell count of 15,600 cells $/ \mathrm{mm}^{3}$, a neutrophil percentage of $71 \%$, a platelet count of 27,000 cells $/ \mathrm{mm}^{3}$, an aspartate aminotransferase level of $161 \mathrm{IU} / \mathrm{mL}$, a sodium level of 136 $\mathrm{mmol} / \mathrm{L}$, a C-reactive protein level of $11.1 \mathrm{mg} / \mathrm{dL}$, and hypoalbuminemia. Despite the treatment, the RCA aneurysm enlarged progressively, reaching $14.2 \mathrm{~mm}$ in maximal diameter by hospital day 23 of the illness, as shown by echocardiography (Figure 1). At 2:00 AM on hospital day 24, the patient suddenly lost consciousness, bradycardia developed, and the radial arterial pulse was not palpable. Despite immediate cardiopulmonary resuscitation, the heart was not beating and did not begin to beat even with open heart massage. After median sternotomy and pericardiotomy, the RCA aneurysm rupture was confirmed. We attempted to suture the ruptured coronary arterial wall, but it was too fragile to suture. The heart did not regain spontaneous contractions, even with extracorporeal membrane oxygenation support for 5 days, and the patient died. Pathologic studies revealed thickened aneurysmal wall with the presence of the inflammatory.
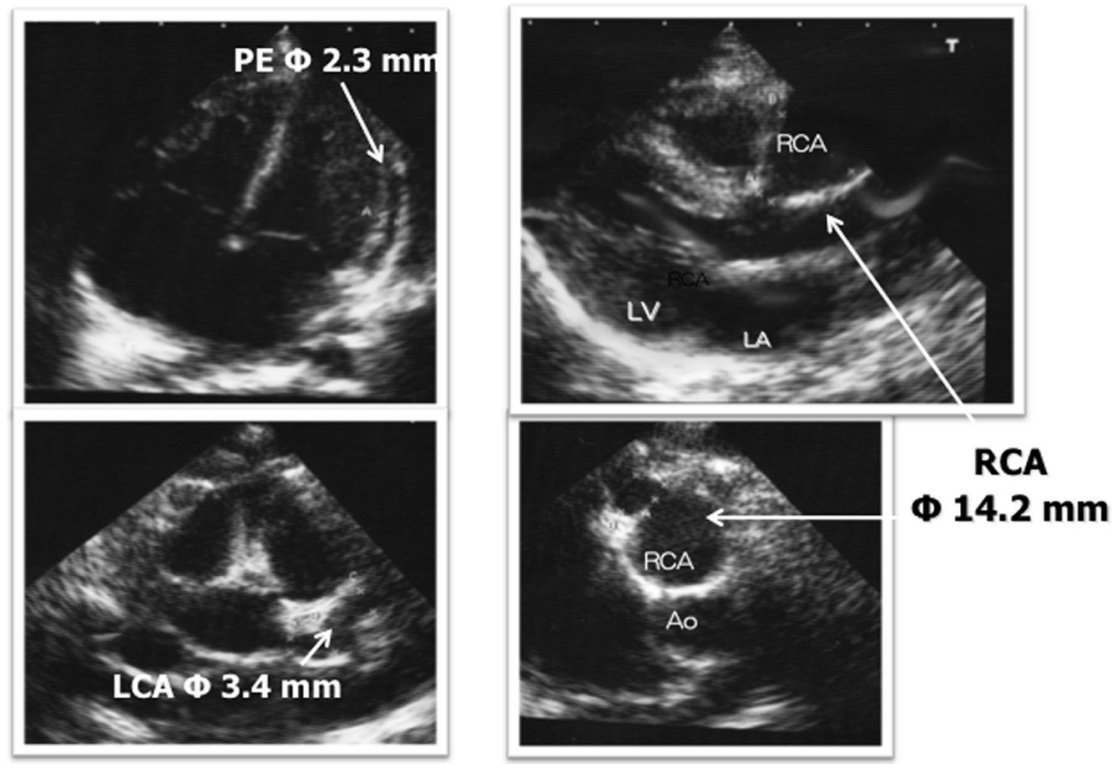

FIGURE 1. Preoperative echocardiographic images. Images to right demonstrate markedly enlarged vessels (arrows) and pericardial effusion ( $P E)$. RCA, Right coronary artery; $L V$, left ventricle; $L A$, left atrium; $L C A$, left circumflex coronary artery; $A o$, aorta; $\Phi$, diameter. 
TABLE 1. Summary of medical course of the ruptured coronary artery aneurysm

\begin{tabular}{|c|c|c|c|c|c|c|c|c|c|c|}
\hline Study & Study design & Age & Sex & $\begin{array}{c}\text { Fever onset to } \\
\text { presentation (d) }\end{array}$ & $\begin{array}{l}\text { Fever onset to } \\
\text { treatment (d) }\end{array}$ & IVIG (mg/kg) & Steroid & $\begin{array}{l}\text { Fever onset } \\
\text { to rupture (d) }\end{array}$ & Surgical procedure & Outcome \\
\hline \multirow[t]{2}{*}{ Rowley, 1997, US } & $\begin{array}{l}\text { Case report } \\
\text { (autopsy) }\end{array}$ & $10 \mathrm{y}$ & Boy & - & - & 2000 for $1 \mathrm{~d}$ & - & 13 & None & Died \\
\hline & $\begin{array}{l}\text { Case report } \\
\text { (autopsy) }\end{array}$ & $22 \mathrm{mo}$ & Girl & - & - & None & - & Unknown & None & Died \\
\hline Koutlas, 1997, US & Case report & $3 \mathrm{y}$ & Boy & - & 14 & 2000 for $1 \mathrm{~d}$ & - & 16 & $\begin{array}{l}\text { CABG, then PCPS, } \\
\text { then transplant } \\
\text { (POD 4) }\end{array}$ & Survived \\
\hline Suzuki, 1999, Japan & $\begin{array}{l}\text { Case report } \\
\text { (autopsy) }\end{array}$ & $4 \mathrm{y}$ & Girl & 4 & 6 & 400 for $5 \mathrm{~d}$ & + & 22 & None & Died \\
\hline Maresi, 2001, Italy & $\begin{array}{l}\text { Case report } \\
\text { (autopsy) }\end{array}$ & $2 \mathrm{mo}$ & Boy & - & - & - & - & 7 & None & Died \\
\hline $\begin{array}{l}\text { Vanlieferinghen, } \\
\text { 2002, France }\end{array}$ & $\begin{array}{l}\text { Case report } \\
\text { (autopsy) }\end{array}$ & $6 \mathrm{mo}$ & Girl & 7 & - & - & - & 14 & None & Died \\
\hline Donna, 2003, US & $\begin{array}{l}\text { Case report } \\
\text { (autopsy) }\end{array}$ & $11 \mathrm{mo}$ & Boy & 4 & - & - & - & 16 & None & Died \\
\hline Mok, 2003, China & Case report & $5 \mathrm{y}$ & Boy & - & 9 & 400 for $3 \mathrm{~d}$ & - & 29 & $\begin{array}{l}\text { Pericardial window } \\
\text { at bedside, then } \\
\text { emergency CABG } \\
\text { with SVG }\end{array}$ & Survived \\
\hline $\begin{array}{l}\text { Wilson, 2004, } \\
\text { New Zealand }\end{array}$ & $\begin{array}{l}\text { Case series } \\
\text { (autopsy) }\end{array}$ & $2 \mathrm{mo}$ & Girl & 2 & 3 & $+($ no details $)$ & - & 3 & None & Died \\
\hline Imai, 2006, Japan & $\begin{array}{l}\text { Case series } \\
\text { (autopsy) }\end{array}$ & $5 \mathrm{y}$ & Boy & 2 & 3 & $+($ no details $)$ & - & 13 & None & Died \\
\hline $\begin{array}{l}\text { Miyamoto, 2013, } \\
\text { Japan }\end{array}$ & $\begin{array}{l}\text { Case series } \\
\quad \text { (autopsy) }\end{array}$ & $3 \mathrm{mo}$ & Boy & 2 & 4 & 2000 for $2 \mathrm{~d}$ & + & 24 & $\begin{array}{l}\text { Pericardial window, } \\
\text { repair of raptured } \\
\text { CAA with direct } \\
\text { closure. }\end{array}$ & Died \\
\hline
\end{tabular}

None of the reports listed cyclosporine use. $I V I G$, Intravenous immunoglobulin; $C A B G$, coronary artery bypass grafting; $P C P S$, percutaneous cardiopulmonary support; $P O D$, postoperative day; $S V G$, saphenous vein graft; $C A A$, coronary artery aneurysm.

\section{DISCUSSION}

Rupture of a coronary aneurysm can occur within the first few months after Kawasaki disease, but it is an exceedingly rare occurrence. As of our last search date (September, 1 2013), a total of 9 other studies incorporating 10 patients have described variations in the ruptured CAA since in 1997 (Tables 1 and 2). Among these, the aneurysms became apparent within 1 to 2 weeks after the onset of fever, rather than the usual course of 2 to 3 weeks. Leukocytosis was found to be typical during the acute stage of Kawasaki disease, with a predominance of immature and mature granulocytes. Approximately 50\% of patients had reported white blood cell counts exceeding 10,000 cells $/ \mathrm{mm}^{3}$. Acute-phase reactants, such as C-reactive protein, were rapidly elevated within 2 weeks in 3 cases. On the basis of histologic investigation of 37 autopsy cases, Amano and colleagues ${ }^{1}$ classified arterial lesions into the following 6 types according to the morphogenesis of arteritis: (1) endothelial degeneration and increased vascular permeability, (2) edema and degeneration of media, (3) necrotizing panarteritis, (4) granulation formation, (5) scar formation, and (6) aneurysm formation. In our case of a ruptured CAA, the wall of the aneurysm showed various changes according to the duration of the disease. Efficacy of IVIG and steroid (prednisolone at $2 \mathrm{mg} / \mathrm{kg} / \mathrm{d}$ ) therapy has been reported in the treatment of severe Kawasaki disease. Patients should be treated with 2 -g/kg IVIG in a single infusion accompanied by aspirin. ${ }^{2}$ This therapy should be started within the first 10 days of illness, as manifested by elevated C-reactive protein. About $20 \%$ of patients with Kawasaki disease do not have relief from fever with the initial IVIG plus aspirin therapy ${ }^{3}$; however, the effects of steroids on coronary artery abnormalities are still unknown. An immunologic study has shown that hypercytokinemia is observed in patients with Kawasaki disease and that cytokines are elevated in the acute phase of Kawasaki disease. It has been reported that inflammatory cytokines are elevated in the acute phase of Kawasaki disease, and IVIG and prednisolone rapidly ameliorate symptoms by reducing cytokine levels. Inflammatory cytokines may mediate endothelial damage and lead to coronary artery abnormalities. ${ }^{4,5}$ According to a previous study, however, some patients who died of ruptured CAA were treated with IVIG and steroids, and most patient had progressive enlarging coronary aneurysms larger than $10 \mathrm{~mm}$ in diameter. ${ }^{5}$ We think that patients with enlarged coronary aneurysms should be monitored closely, and optimal surgical timing is within 1 month after the onset of the fever. Especially in cases with giant aneurysm larger than $10 \mathrm{~mm}$ in diameter with rapid progressive enlargement, despite intensive care, control of blood pressure, and heart rate with $\beta$-blockers or calciumchannel antagonists under general anesthesia, we should 
TABLE 2. Summary of laboratory and cardiac findings of the ruptured coronary artery aneurysm

\begin{tabular}{|c|c|c|c|c|c|c|c|c|c|}
\hline Study & $\begin{array}{c}\mathbf{H b} \\
(\mathrm{g} / \mathrm{dL})\end{array}$ & $\begin{array}{c}\text { WBCs } \\
\left(\times 10^{3} / \mathbf{m m}^{3}\right)\end{array}$ & $\begin{array}{l}\text { Platelets } \\
\left(\times 10^{3} / \mathbf{m m}^{3}\right)\end{array}$ & $\begin{array}{c}\text { AST } \\
(\mathbf{I U} / \mathbf{L})\end{array}$ & $\begin{array}{c}\text { ALT } \\
(\mathbf{I U} / \mathbf{L})\end{array}$ & $\begin{array}{c}\text { CRP } \\
(\mathbf{m g} / \mathbf{d L})\end{array}$ & Echocardiogram & $\begin{array}{c}\text { Ruptured } \\
\text { position }\end{array}$ & Pathology \\
\hline \multirow[t]{2}{*}{ Rowley, 1997, US } & - & - & - & - & - & - & - & - & $\begin{array}{l}\text { Inflammatory cells present in intima, } \\
\text { media, and adventitia of vessels; } \\
\text { IgA-producing cells present in all } \\
3 \text { layers }\end{array}$ \\
\hline & - & - & - & - & - & - & - & - & $\begin{array}{l}\text { Inflammatory cells present in intima, } \\
\text { media, and adventitia of vessels; } \\
\text { IgA-producing cells present in all } \\
3 \text { layers }\end{array}$ \\
\hline Koutlas, 1997, US & 9.0 & 20 & 835 & - & - & - & Day 15 , LMCA $15 \mathrm{~mm}$, RCA $5 \mathrm{~mm}$ & LMCA & - \\
\hline Suzuki, 1999, Japan & 10.0 & 11.3 & 22 & 184 & 181 & 21.0 & $\begin{array}{l}\text { Day 6, LMCA } 4 \mathrm{~mm} \text {, RCA } 3.3 \mathrm{~mm} \text {; } \\
\text { day } 15 \text {, LMCA } 5 \mathrm{~mm} \text {, RCA, } 4 \\
\text { mm; day } 22 \text {, giant aneurysm, } \\
\text { LMCA } 15 \mathrm{~mm}, \text { RCA } 10 \mathrm{~mm}\end{array}$ & $\begin{array}{l}\text { LMCA }(0.7-3 \mathrm{~cm} \\
\text { from ostium) }\end{array}$ & $\begin{array}{l}\text { Proliferation of fibroblasts and } \\
\text { myofibroblasts; inflammatory } \\
\text { infiltrates of lymphocytes and } \\
\text { plasma cells }\end{array}$ \\
\hline Maresi, 2001, Italy & - & 27.59 & 895 & - & - & - & - & $\begin{array}{l}\text { LMCA }(1 \mathrm{~cm} \\
\text { from ostium) }\end{array}$ & $\begin{array}{l}\text { At site of rupture, inflamed wall } \\
\text { epicardium; similar inflammation } \\
\text { in adventitia of remaining } \\
\text { coronary vessels }\end{array}$ \\
\hline $\begin{array}{l}\text { Vanlieferinghen, } \\
\text { 2002, France }\end{array}$ & - & 11.7 & - & - & - & - & - & LMCA & $\begin{array}{l}\text { Autopsy showed cardiac tamponade } \\
\text { caused by important ruptured } \\
\text { aneurysm of LCA }\end{array}$ \\
\hline Donna, 2003, US & - & - & - & - & - & - & - & Proximal LAD & $\begin{array}{l}\text { Massive vessel wall destruction } \\
\text { characterized by loss of elastic } \\
\text { and muscular layers due to dense } \\
\text { lymphoplasmacytic infiltrate }\end{array}$ \\
\hline Mok, 2003, China & - & - & 111 & - & - & - & $\begin{array}{l}\text { Day 6, LMCA } 4.7 \mathrm{~mm} \text {, RCA } 18.6 \\
\text { mm; day } 28 \text {, RCA } 30 \mathrm{~mm}\end{array}$ & Proximal RCA & Not listed \\
\hline $\begin{array}{l}\text { Wilson, 2004, } \\
\text { New Zealand }\end{array}$ & - & - & - & - & - & - & - & Proximal LAD & $\begin{array}{l}\text { Severe segmental necrotizing } \\
\text { arteritis of all coronary arteries; } \\
\text { mild to moderate fibrous intimal } \\
\text { proliferation associated focally } \\
\text { with organizing thrombus; focal } \\
\text { fibrinoid necrosis }\end{array}$ \\
\hline Imai, 2006, Japan & - & 29.4 & - & - & - & 16.6 & $\begin{array}{l}\text { Day 7, LAD } 8.1 \mathrm{~mm} \text {; day } 12 \text {, LAD } \\
\quad 18 \mathrm{~mm}\end{array}$ & Proximal LAD & $\begin{array}{l}\text { Inflammatory cell infiltration in } \\
\text { proximal or distal portion of } \\
\text { aneurysm in both right and left } \\
\text { coronary arteries, more prominent } \\
\text { in intima and adventitia than } \\
\text { media; fibrocellular intimal } \\
\text { thickening, rich in cells including } \\
\text { smooth muscle cells, covering } \\
\text { media }\end{array}$ \\
\hline $\begin{array}{l}\text { Miyamoto, 2013, } \\
\text { Japan }\end{array}$ & 7.2 & 15.6 & 27 & 161 & 120 & 11.1 & $\begin{array}{l}\text { Day } 13 \text {, RCA } 5.0 \mathrm{~mm} \text {, LCA } 3.1 \mathrm{~mm} \text {; } \\
\text { day } 23 \text {, RCA } 14.2 \mathrm{~mm}\end{array}$ & Proximal RCA & $\begin{array}{l}\text { Internal elastic membrane of } \\
\text { coronary artery wall disappeared, } \\
\text { leading to rupture and extending } \\
\text { artery wall under influence of } \\
\text { blood pressure }\end{array}$ \\
\hline
\end{tabular}

$\overline{H b}$, Hemoglobin; WBCs, white blood cells; $A S T$, aspartate aminotransferase; $A L T$, alanine aminotransferase; $C R P$, C-reactive protein; $L M C A$, left main coronary artery; $R C A$, right coronary artery; $L A D$, left anterior descending coronary artery; $L C A$, left circumflex coronary artery; —, not listed in thesis.

suspect the possibility of the rupture. The patient should undergo coronary artery bypass grafting as soon as possible. Early intervention may offer the only chance for survival.

We thank Robert E. Brandt, founder, CEO, and CME of MedEd Japan, for editing the manuscript.

\section{References}

1. Amano S, Hazama F, Hamashima Y. Pathology of Kawasaki disease: I. Pathology and morphogenesis of the vascular changes. Jpn Circ J. 1979;43:633-43.

2. Kobayashi T, Saji T, Otani T, Takeuchi K, Nakamura T, Arakawa H, et al, RAISE study group investigators. Efficacy of immunoglobulin plus prednisolone for prevention of coronary artery abnormalities in severe Kawasaki disease (RAISE study): a randomised, open-label, blinded-endpoints trial. Lancet. 2012;379: 1613-20.

3. Nakamura Y, Yashiro M, Uehara R, Sadakane A, Tsuboi S, Aoyama Y, et al. Epidemiologic features of Kawasaki disease in Japan: results of the 2009-2010 nationwide survey. J Epidemiol. 2012;22:216-21.

4. Newburger JW, Sleeper LA, McCrindle BW, Minich LL, Gersony W, Vetter VL, et al, Pediatric Heart Network Investigators. Randomized trial of pulsed corticosteroid therapy for primary treatment of Kawasaki disease. N Engl J Med. 2007; $15: 663-75$

5. Okada Y, Shinohara M, Kobayashi T, Inoue Y, Tomomasa T, Kobayashi T, et al Effect of corticosteroids in addition to intravenous gamma globulin therapy on serum cytokine levels in the acute phase of Kawasaki disease in children. J Pediatr. 2003;143:363-7. 